\title{
Variability of deep chlorophyll maximum characteristics in the Northwestern Mediterranean
}

\author{
Marta Estrada ${ }^{1}$, Celia Marrasé ${ }^{1}$, Mikel Latasa ${ }^{1}$, Elisa Berdalet ${ }^{1}$, \\ Maximino Delgado ${ }^{1}$, Tecla Riera ${ }^{2}$ \\ ${ }^{1}$ Institut de Ciències del Mar, P. Nacional, E-08039 Barcelona, Spain \\ ${ }^{2}$ Facultat de Biologia, Universitat de Barcelona, Diagonal 645, E-08028 Barcelona, Spain
}

\begin{abstract}
A well-developed deep chlorophyll maximum (DCM) is a prominent feature of the Northwestern Mediterranean during a large part of the year. Data from 7 oceanographic surveys carried out across the Catalano-Balearic Sea, between 1982 and 1987, have been used to analyze shortterm (within cruises) and seasonal+interannual (between cruises) variation of several parameters (such as surface and DCM chlorophyll concentration, integrated chlorophyll, DCM, nitracline and nitrite maximum depths). Significant positive correlations $(p<0.01)$ were found between the depths of the $\mathrm{DCM}$, of the nitracline and of the nitrite maximum. Surface chlorophyll concentrations and average chlorophyll values for the upper $110 \mathrm{~m}$ of the water column were signicantly correlated for only 2 of the 7 cruises. The relationship between integrated primary production and surface or integrated chloro. phyll concentrations presented considerable scatter due, in part, to physiological variability of the sam. pled communities. After exclusion of 1 statistically outlying point, apparently corresponding to a sedimenting bloom, a multiple linear regression model of integrated primary production $\left(\mathrm{mg} \mathrm{C}^{-2} \mathrm{~h}^{-1}\right)$ on integrated chlorophyll, euphotic zone depth and a stability parameter explained $74 \%$ of the data variance. However, the presence of such 'outliers' limits the usefulness of these models and stresses the need of physiological information for a reliable prediction of primary productivity.
\end{abstract}

\section{INTRODUCTION}

Deep chlorophyll maxima are ubiquitous in oligotrophic situations such as those found in the major oceanic gyres of the Atlantic and the Pacific and in temperate areas in summer. In general, the water column of these regions presents a series of common properties, which have been characterized as the 'Typical Tropical Structure' or TTS by Herbland \& Voituriez (1979). In the TTS, the upper layers of the euphotic zone are nutrient-depleted, the lower levels are light-limited, and a deep chlorophyll maximum (DCM) occurs within the layer of density stratification, in close association with the nutricline. Based on the relationships between hydrographical and biological features described by Herbland \& Voituriez (1979), the TTS can be considered as a continuum of pattern controlled by the input of nutrients from below (Cullen 1982). The oligotrophic extreme of this continuum presents a deep DCM and nitracline, low chlorophyll concentrations and low primary production. More productive situations, with relatively high chlorophyll concentrations and primary production, are characterized by a shallow DCM and nitracline.

A well-developed deep chlorophyll maximum associated with increased phytoplankton biomass, is a prominent feature of the Mediterranean Sea during a large part of the year (Estrada 1985a, Berman et al. 1984). The presence of a DCM plays an important role in the way the trophic food web of the pelagic ecosystem is organized (Fairbanks \& Wiebe 1980, Laws et al. 1987). In the Catalano-Balearic Sea (Fig. 1), the contribution of the DCM (assuming it to be $15 \mathrm{~m}$ wide) to summer primary production has been estimated to range from 12 to $30 \%$ of the total (Estrada 1985a). The accumulation of phytoplankton biomass at the DCM, 


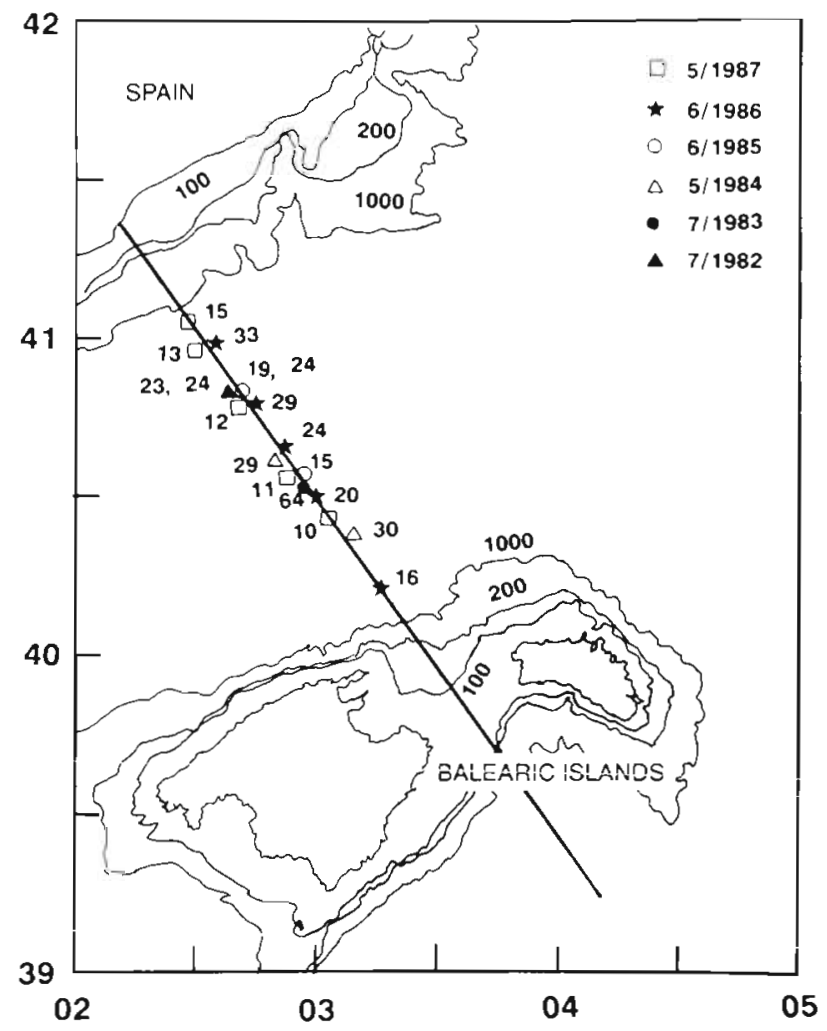

Fig. 1. Study area in the Catalano-Balearic Sea. Line indicates the transect sampled during the different cruises. Numbers indicate the position of the biological stations from which the primary production data were obtained. Symbols indicate the cruises

together with fertilization events related to oceanographic features such as the Catalan and the Balearic frontal systems (Estrada \& Margalef 1988), may help to explain the relatively high production estimated for upper trophic levels in the Mediterranean (Sournia 1973).

The Western Mediterranean DCM appears to be closely associated with the nitracline (Estrada 1985a, b, Lohrenz et al. 1988) and has been compared to the TTS of Herbland \& Voituriez (1979). However, while a number of publications deal with the characteristics of the DCM in areas of the Atlantic and Pacific oceans (Anderson 1969, Venrick et al. 1973, Kiefer et al. 1976 , Cullen \& Eppley 1981, Cox et al. 1982, Herbland et al. 1983. Napp 1987. Eppley et al. 1988) information on the variability of the Mediterranean DCM is scarce.

In this paper, we attempt to compare seasonal and short-term changes in several hydrographic variables concerning the DCM in the Catalan Sea, and examine the relationships between primary production and several characteristics of the distribution of biological and physical variables in the water column. The goal of the present work was to gain insight into the ecological significance of the observed distributions and to assess the usefulness of these relationships for predictive purposes and as a basis for remote sensing applications (Platt \& Sathyendranath 1988, Banse \& Yong 1990, Balch et al. 1992). The data were obtained in a series of oceanographic cruises carried out across the Catalan front, along a transect from Barcelona to the channel between Mallorca and Menorca. The large extension of the marine regions in which phytoplankton biomass and production accumulate at subsurface levels stresses the importance of finding regularities in the physical and biological features of these areas. In this context, it can be expected that studies carried out in a limited, but well-characterized, zone can offer information of general ecological interest.

\section{MATERIAL AND METHODS}

The oceanographic cruises discussed in this work took place between Juiy 1982 and June 1987 (Table 1). Details of the sampling strategy and basic data from all cruises are given in PEPS (1986) and Masó \& PEPS (1988). Information concerning chlorophyll a distribution and primary production values during the PEP 82, PEP 83 and.PEP 84 cruises can be found in Estrada (1985a, b) and Estrada \& Margalef (1988). PEP stands for 'Producció Estival Profunda' ('Deep Summer Production' in the Catalan language). Aspects of the phytoplankton composition during some of the cruises have been discussed in Estrada (1985a, b, 1991), Margalef (1985), Margalef \& Estrada (1987) and Estrada \& Salat (1989)

Sampling was conducted mainly along a transect between Barcelona and the Mallorca-Menorca channel (Fig. 1). Each cruise consisted of series of 'standard' and 'biological' stations. In general, at each 'standard' station, water samples were taken with 51 Niskin bottles at $10 \mathrm{~m}$ intervals between surface and $110 \mathrm{~m}$, and at larger intervals from this depth down to at least $400 \mathrm{~m}$. Several stations could be occupied each day, so that a transect was completed in 2 to $3 \mathrm{~d}$ (see Table 1 ). The 'biological' stations lasted $24 \mathrm{~h}$ and consisted of an

Table 1 Cruise dates. Code (month/year) is the abbreviation used in Figs. 1, 7, 8 \& 9

\begin{tabular}{|lrr|}
\hline Cruise & \multicolumn{1}{c}{ Date } & Code \\
\hline PEP 82 & 12-20 Jul 1982 & $7 / 1982$ \\
PEP 83 & 8-14 Jul 1983 & $7 / 1983$ \\
PEP 84 & 16-27 May 1984 & $5 / 1984$ \\
PEP 85 & 1-6 Jun 1985 & $6 / 1985$ \\
PEP 86 & 13-24 Jun 1986 & $6 / 1986$ \\
FRONTS 11/86 & $7-12$ Nov 1986 & $11 / 1986$ \\
PEP 87 & 23-30 May 1987 & $5 / 1987$ \\
\hline
\end{tabular}


initial hydrographical cast similar to that of the 'standard' stations, followed by repeated casts ('production' casts) at selected depths to obtain water for several biological determinations, including ${ }^{14} \mathrm{C}$ uptake experiments. The stations were classified into those belonging to the Catalan coast (coastal, depths $<1000 \mathrm{~m}$ ), central zone (depths $>1000 \mathrm{~m}$ ), Balearic sill (depths $<1000 \mathrm{~m}$ ) and east of the Balearic Islands. Previous inspection of the data had shown that there were differences in the degree of stratification of the water column and other oceanographic parameters among these groups. As most of the stations of our data set belonged to the central zone, we considered only these in the statistical calculations.

In cruises PEP 82 and PEP 83, temperature readings were obtained with a Neil Brown CTD probe. In the remaining cruises, temperature was measured with reversing thermometers and salinity with an induction salinometer (PEPS 1986, Masó \& PEPS 1988). The difference between the $\sigma_{t}$ values at the DCM depth and at surface, divided by the DCM depth and multiplied by $100\left(D_{\text {sigt }}\right)$, was used as an index of stability of the upper water column (see definitions in Table 2). Chlorophyll a was determined by fluorimetry of acetone extracts (Yentsch \& Menzel 1963). Seawater volumes from 25 to $200 \mathrm{~cm}^{3}$ were filtered through GF/C glass fiber filters (nominal pore size $1.2 \mu \mathrm{m}$ ) in PEP 82, PEP 83 and PEP 84 , and through GF/F filters (nominal pore size $0.7 \mu \mathrm{m}$ ) in the following cruises. The filters were subsequently homogenized in $90 \%$ acetone, and the suspension was cleared by centrifugation. The fluorescence of the chlorophyll extracts was determined by means of a Turner 111 in cruises PEP 82, PEP 83 and PEP 84, and a Turner Designs fluorometer in the following cruises. Nutrients were determined using Technicon autoanalyzers, as described in PEPS (1986) and Masó \& PEPS (1988). Underwater irradiance was measured at the biological stations with a $2 \pi$, LI-COR underwater quantum sensor.

The use of GF/C filters during the first 3 cruises may have resulted in an underestimation of the chlorophyll a concentration (Phinney \& Yentsch 1983). However, both GF/C (nominal pore size $1.2 \mu \mathrm{m}$ ) and GF/F (nominal pore size $0.7 \mu \mathrm{m}$ ) filters retain a higher proportion of small particles than could be expected from their nominal pore sizes (Sheldon 1972, Venrick et al. 1987). In a study carried out in coastal and oligotrophic open sea areas of the North Pacific, Venrick et al. (1987) found that GF/C filters passed, on average, from 4.4 to $8.9 \%$ of total chlorophyll (retained by $0.45 \mu \mathrm{m}$ Millipore filters). Parallel measurements using GF/C and $0.4 \mu \mathrm{m}$ Nuclepore filters were carried out at 1 station of PEP 82 and PEP 83 and 2 stations of PEP 84, for samples from 0 to $90 \mathrm{~m}$ depth. No significant differences were detected using the signed rank test. Although these results cannot be extended to all the situations encountered and comparisons of chlorophyll concentrations among cruises must be made with caution, they suggest that the bias resulting from the change of filter type is likely to have been fairly small.

Table 2. Abbreviations employed in the text. For clarity, capital letters without subindices have been used in the figures (e.g. $\mathrm{Chl}_{\max }=$ (HLMAX)

\begin{tabular}{|c|c|c|}
\hline Abbreviation & Definition & Units \\
\hline $\mathrm{Ch} l_{\max }$ & Chlorophyll a concentration at the DCM & $\mathrm{mg} \mathrm{m}^{-3}$ \\
\hline $\mathrm{Ch} \mathrm{l}_{\text {mean }}$ & Average chlorophyll $a$ between 0 and $110 \mathrm{~m}$ depth & $\mathrm{mg} \mathrm{m} \mathrm{m}^{-3}$ \\
\hline $\mathrm{Chl}_{\text {tot }}$ & Total chlorophyll a between 0 and $110 \mathrm{~m}$ depth & $\mathrm{mg} \mathrm{m}^{-3}$ \\
\hline Chlor 0 & Surface chlorophyll a & $\mathrm{mg} \mathrm{m} \mathrm{m}^{-3}$ \\
\hline Chlor $_{\text {int }}$ & Integrated chlorophyll a down to the $1 \%$ light level & $\mathrm{mg} \mathrm{m}^{-2}$ \\
\hline DCM & Deep chlorophyll maximum & - \\
\hline$D_{\text {sIgt }}$ & $\left(\sigma_{t}\right.$ at the $\mathrm{DCM}-\sigma_{t}$ at $\left.0 \mathrm{~m}\right) \times 100 / \mathrm{ZDCM}$ & - \\
\hline $\mathrm{P}^{\mathrm{B}} \mathrm{DCM}$ & Productivity index at the DCM & $\operatorname{mgC}(\mathrm{mgchl} a)^{-1} \mathrm{~h}^{-1}$ \\
\hline $\mathrm{P}_{\max }^{\mathrm{B}}$ & Maximum productivity index in the water column & $\mathrm{mgC}(\mathrm{mg} \mathrm{chl} \alpha)^{-1} \mathrm{~h}^{-1}$ \\
\hline Prod day $_{\text {da }}$ & Daily integrated primary production down to the $1 \%$ light level & $\mathrm{mgC} \mathrm{m} \mathrm{m}^{-2} \mathrm{~d}^{-1}$ \\
\hline $\operatorname{Prod}_{\mathrm{n} \mathrm{t}}$ & $\begin{array}{l}\text { Hourly integrated primary production down to the } 1 \% \text { light level, at mid-day } \\
(8: 30 \text { to } 15: 15 \text { h GMT) }\end{array}$ & $\mathrm{mgC} \mathrm{m} \mathrm{Ch}^{-1}$ \\
\hline$P / B$ & Ratio between Prod $_{\text {int }}$ and Chlor $_{\text {int }}$ & $\mathrm{mgC}(\mathrm{mg} \mathrm{chl} \mathrm{a})^{-1} \mathrm{~h}^{-1}$ \\
\hline Tempo & Surface temperature & ${ }^{\circ} \mathrm{C}$ \\
\hline$Z_{C C}$ & Depth of the centroid of the chlorophyll distribution & $\mathrm{m}$ \\
\hline$Z_{\text {eu }}$ & Depth of the $1 \%$ light level & $\mathrm{m}$ \\
\hline$Z_{\mathrm{DCM}}$ & DCM depth & $\mathrm{m}$ \\
\hline$Z_{\mathrm{NO} 2}$ & Depth of the nitrite maximum & $\mathrm{m}$ \\
\hline$Z_{\mathrm{NO} 3}$ & Nitracline depth & $\mathrm{m}$ \\
\hline VSI & Vertical stratification index (see methods) & - \\
\hline
\end{tabular}


For the hydrographical casts, vertically integrated chlorophyll $\left(\mathrm{Chl}_{\text {tol }}\right)$ or mean chlorophyll concentration ( $\mathrm{Chl}_{\text {mean }}$ ) between 0 and $Z_{\mathrm{n}} \mathrm{m}$ depth was calculated from:

$$
\begin{gathered}
\mathrm{Chl}_{\mathrm{tot}}=\sum_{i=1}^{\mathrm{n}-1}\left(C_{j+1}+C_{i}\right)\left(Z_{i+1}-Z_{i}\right) / 2 \\
\text { and } \mathrm{Chl} \text { mean }=\mathrm{Chl}_{\mathrm{tot}} / Z_{\mathrm{n}}
\end{gathered}
$$

where $C_{\mathrm{i}}=$ the concentration in the $i$ th sample, $Z_{i}=$ depth of the $i$ th sample and $n=$ no. of samples. The $Z_{n}$ value used for the calculations was $110 \mathrm{~m}$. This was the deepest level sampled at $10 \mathrm{~m}$ intervals, because it was located well below the DCM. While $\mathrm{Chl}_{\mathrm{tot}}$ is only slightly underestimated by this choice (see Figs. 2 \& 3 ), it has to be taken into account that the range of $\mathrm{Chl}_{\text {mean }}$ is dependent on the reference level.

The depth centroid of the vertical distribution of chlorophyll $\left(Z_{C C}\right)$ was calculated according to the formula (Herman 1989):

$$
Z_{\mathrm{CC}}=\sum_{i=1}^{\mathrm{n}-1}\left(C_{1+1}+C_{i}\right)\left(Z_{1+1}-Z_{i}\right)\left(Z_{t+1}+Z_{i}\right) /\left(4 \times \mathrm{Chl}_{\mathrm{tot}}\right)
$$

The $Z_{\mathrm{CC}}$ was included as a descriptor of the chlorophyll profile because it is less subject to sampling variability than the DCM depth. We found that its value at a particular location tended to vary little within the duration of a cruise (data not shown).

The vertical stratification index (VSI; Cullen \& Eppley 1981. Napp 1987) was chosen to characterize the degree of heterogeneity of the vertical chlorophyll a profiles. The formula used was:

$$
\text { VSI }=100\left(\sum_{i=1}^{n-1}\left|C_{i+1}-C_{i}\right|\right) /\left(Z_{n} \times C h 1_{\text {tot }}\right)
$$

Phytoplankton abundances were determined for samples from the initial cast of the biological stations of PEP 86 and the hydrographical stations of the other cruises. Additional samples were taken from some of the production casts of the biological stations. The samples for phytoplankton enumeration consisted of $120 \mathrm{ml}$ of water which were enclosed in Pyrex bottles and fixed with Lugol's solution (without acetic acid). A subsample $(100 \mathrm{ml})$ was sedimented in a composite chamber and observed with an inverted microscope. This methodology is not adequate for picoplankton and for many naked flagellates which deteriorate in fixed samples. More technical details are given in Estrada (1985a).

Primary production determinations using the ${ }^{14} \mathrm{C}$ uptake technique were carried out in all cruises except FRONTS $11 / 86$. The position of the corresponding sta- tions is given in Fig. 1 (on 4 occasions, 2 experiments were carried out at the same station). The methodology was basically as described in Estrada (1985b). Two clear and 1 opaque $125 \mathrm{ml}$ Pyrex bottles were filled with water from 6 selected depths ( 3 of them covering the DCM) and inoculated with $5 \mu \mathrm{Ci}$ of $\mathrm{NaH}^{14} \mathrm{CO}_{3}{ }^{-}$. The bottles were kept for 2 to $3 \mathrm{~h}$ in simulated in situ incubators, placed on deck of the ship, and cooled with circulating surface water. The incubators were covered with stainless steel screens to simulate the irradiance at the depths of origin of the samples. One problem with this system is that deep samples were incubated at surface temperatures and were exposed to light of a different spectral composition than that found in situ; the combined effect of these conditions on the corresponding $C$ fixation rates (Lohrenz et al. 1992) is uncertain because, although higher temperatures might cause an overestimation, other factors, such as the temperature change or the differences in light quality, could tend to reduce carbon uptake. Measurements of the productivity indices of DCM samples exposed to increased irradiances, carried out during July 1983 (cruise PEP 83), suggested that adverse effects of the incubation temperature could not have been too important (Estrada 1985b). After incubation, the content of the bottles was filtered through Millipore HAWP membrane filters $10.45 \mu \mathrm{m}$ nominal pore size), which were dried and exposed to $\mathrm{HCl}$ fumes. Radioactivity was measured using a LKB liquid scintillation counter. Dark uptake values were low and no correction was applied. Only data from incubations performed between 8:30 and 15:15 h GMT were retained. Hourly production rates per $\mathrm{m}^{2}\left(\operatorname{Prod}_{\mathrm{m}}\right)$ were calculated by integrating the ${ }^{14} \mathrm{C}$ uptake rates corresponding to the different depths, down to the $1 \%$ light level. Chlorophyll concentrations were also integrated down to the $1 \%$ light level $\left(\mathrm{Chlor}_{i n t}\right)$. Although the compensation depth may have been deeper, it is unlikely that a significant underestimation of $\operatorname{Prod}_{\text {int }}$ occurred, given the low $\mathrm{C}$ fixation rates recorded at $1 \%$ of the surface irradiance and the low chlorophyll concentrations generally found below the corresponding depth. An approximate figure for daily primary production was obtained by multiplying the hourly midday rates by 9 , which was the average ratio (range 8.7 to 9.3 ) between total daily irradiance and the mean hourly irradiance at mid-day for the months of May to July in the Barcelona area (Coronas et al. 1982). That factor was not very different from the slope $(=8$, $p<0.01$ ) of the regression (with zero-intercept) of daily production estimates versus hourly mid-day values for a total of 5 stations of PEP 82, PEP 83 and PEP 84, for which successive incubations during the same day were available (Estrada 1985b). However, the assumption of a linear relationship between surface irradiance 
and production of the water column at a given location (Minas \& Coste 1964) and the application of a single factor should be considered as an approximation.

An approximation to the ratio $\left(\operatorname{Prod}_{\text {day }} / \mathrm{Chlor}_{0}\right)$ between daily integrated production (Prod day) and near-surface chlorophyll, as defined by Eppley et al. (1985), was obtained by extrapolating Prod $_{\text {int }}$ to daily production and dividing by the chlorophyll concentration at surface $\left(\mathrm{Chlor}_{0}\right.$, taken as representative of nearsurface pigments, given that chlorophyll concentrations were fairly homogeneous in the upper 10 to $20 \mathrm{~m}$ of the euphotic zone).

\section{RESULTS}

\section{Seasonal variability of the DCM and environmental factors}

A representative late spring (PEP 86, June 1986) distribution of temperature, salinity and chlorophyll concentration along the studied transect is shown in Fig. 2. Typical vertical profiles of chlorophyll concentration and several hydrographic parameters at one of the central stations are presented in Fig. 3. Outside the
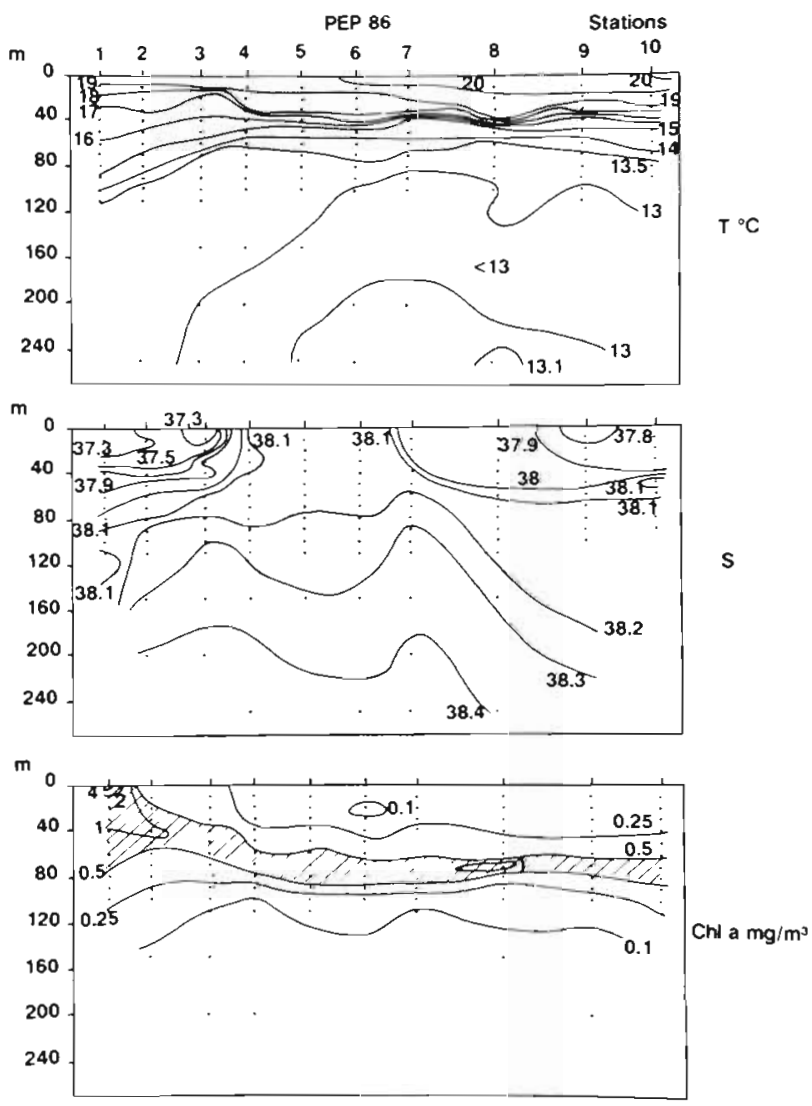

Fig. 2. Distributions of temperature, salinity and chlorophyll a concentration in the first transect of PEP 86

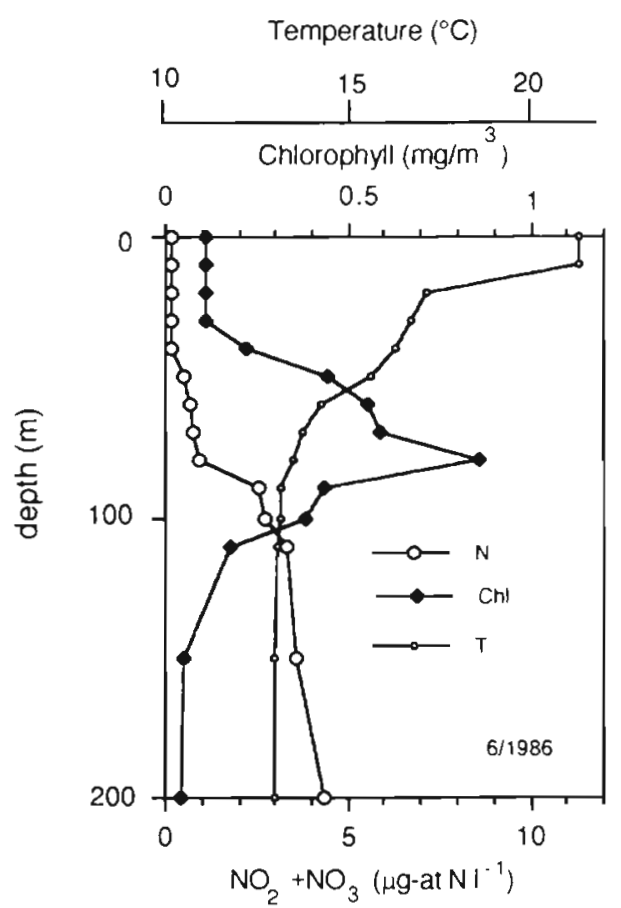

Fig. 3. Representative vertical profiles of temperature, chlorophyll $a$ and nitrate concentration in the central zone (Stn 28,

Fig. 1) of the studied transect, during the cruise PEP 86

winter or early spring period, the surface signature of the Catalan front is only appreciable in the salinity distribution, as happened during PEP 86. The chlorophyll distribution patterns over the shelf are very variable, due to more intense mixing and to the influence of surface tongues of low-salinity and chlorophyll-rich coastal waters (Estrada \& Salat 1989), such as that seen

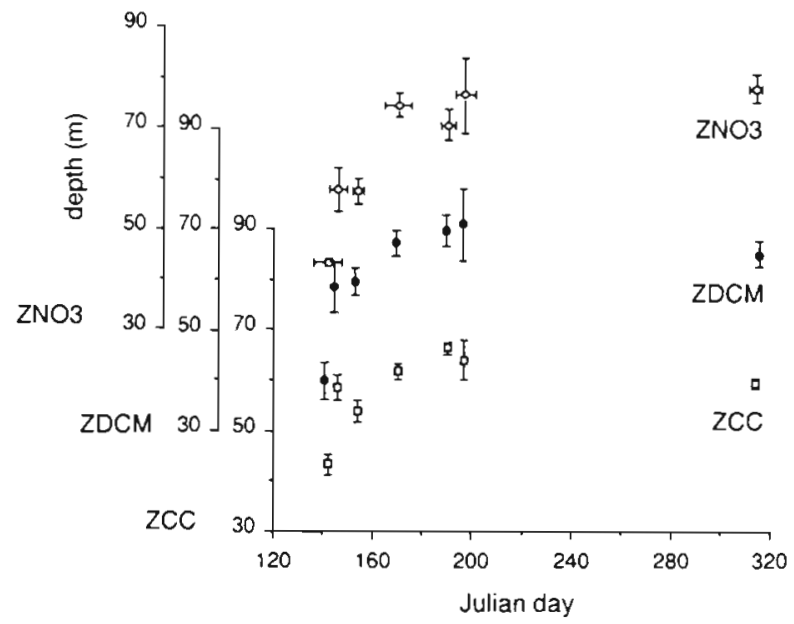

Fig. 4. Seasonal changes of the nitracline depth (ZNO3), the chlorophyll maximum depth (ZDCM), and the depth of the centroid of the chlorophyll distribution (ZCC). Each point corresponds to the average for the different stations of each cruise. Vertical bars indicate the standard error of the mean. Horizontal bars indicate the duration of each cruise 


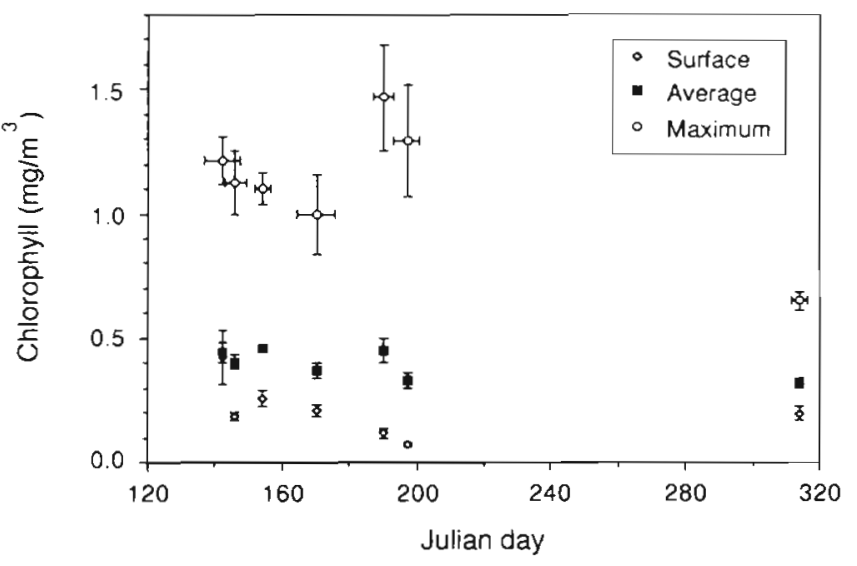

Fig. 5. Seasonal changes of surface chlorophyll a concentration, average chlorophyll a concentration in a layer of 0 to 110 $m$ depth, and concentration of chlorophyll $a$ at the deep maximum. Each point corresponds to the mean for the stations of each cruise. Vertical and horizontal bars as in Fig. 4

in Fig. 2; these tongues are subject to rapid displacement in a southwest direction, with production of meanders and eddies. The doming of the isolines offshore of the Catalan front, approximately mid-way between Barcelona and the Balearic Islands (Fig. 2) is a consistent feature during all the cruises (data not shown) and contributes to increased nutrient inputs into the upper layers of the euphotic zone. Its significance has been discussed in previous papers (Estrada \& Margalef 1988).

The variation of the within-cruise averages of $\mathrm{Chlor}_{0}$ (surface chlorophyll concentration, $\mathrm{mg} \mathrm{m}^{-3}$ ), $\mathrm{Chl}_{\max }$ (chlorophyll concentration at the DCM, $\mathrm{mg} \mathrm{m}^{-3}$ ). $\mathrm{Chl}_{\text {mean }}$ (mean chlorophyll in a water column of 0 to $110 \mathrm{~m}, \mathrm{mg} \mathrm{m} \mathrm{m}^{-3}$ ) and other parameters, for the central stations (deeper than $1000 \mathrm{~m}$ ) of the studied transect, is summarized in Figs. 4 to 6. The depths of the DCM

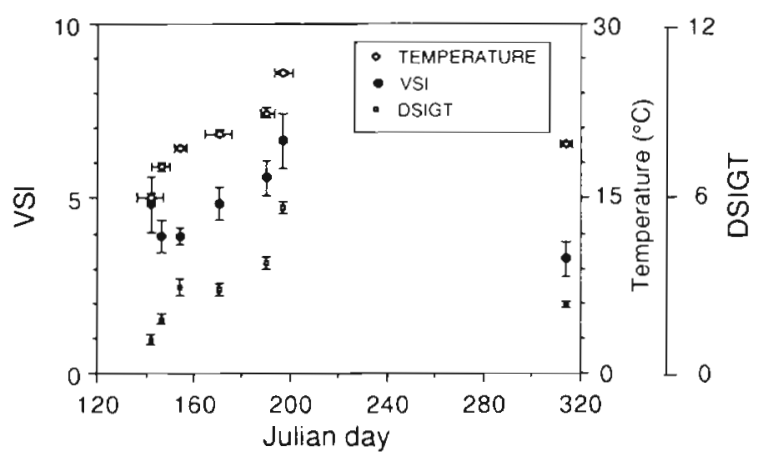

Fig. 6. Seasonal changes of DSIGT (the difference between $\sigma$ at the DCM depth and at surface, divided by the DCM depth and multiplied by 100), vertical stratification index (VSI) and surface temperature (TEMP). Each point corresponds to the mean for the stations of each cruise. Vertical and horizontal bars as in Fig. 4
$\left(Z_{\mathrm{DCM}}\right)$, the nitracline $\left(Z_{\mathrm{NO}_{3}}\right)$ and the centroid of the chlorophyll distribution $\left(Z_{C C}\right)$ increased from spring to summer and decreased again in the fall cruise. The same happened with the surface temperature (Temp $\mathrm{p}_{0}$.

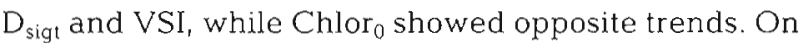
the other hand, the temperature at the DCM (data not shown) varied only between 13 and $14{ }^{\circ} \mathrm{C}$ and $\mathrm{Chl}$ mean did not present any clear seasonal trend. The chlorophyll concentration at the maximum ( $\left.\mathrm{Chl}_{\max }\right)$ appeared to peak in the summer, coinciding with the highest VSI and Temp $_{0}$. The width of the upper mixed layer (data not shown) ranged from less than $10 \mathrm{~m}$ in July to 40-50 $\mathrm{m}$ in early November (cruise F1186).

\section{Relationships among chlorophyll and environmental variables}

The relationships among selected variables from the central zone data set were explored by medns of a correlation matrix (Table 3). The depths of the DCM $\left(Z_{D C M}\right)$, the centroid of the chlorophyll distribution $\left(Z_{C C}\right)$, the nitracline $\left(Z_{\mathrm{NO}_{3}}\right)$ and the nitrite maximum $\left(Z_{\mathrm{NO}_{2}}\right)$ were all positively correlated, as could be expected from observation of the profiles. The relationship between $\mathrm{Chlor}_{0}$ and $\mathrm{Chl}_{\text {mean }}$ was significant but presented considerable scatter (Fig. 7). When the $\mathrm{Chlor}_{0}$ and $\mathrm{Chl}_{\text {mean }}$ data sets were considered separately for each cruise, the correlation between both variables was only significant for PEP 84 and PEP 86 (data not shown).

Table 3. Correlation matrix of parameters measured at the central zone stations. The number of observations was 64 to 69. Significance: $\cdot 0.01<p<0.05 ; \cdots p<0.01$ The key for abbreviations is given in Table 2

\begin{tabular}{|c|c|c|c|c|c|}
\hline Parameter & Chlor $_{0}$ & $\mathrm{Chl}_{\text {mean }}$ & $\mathrm{ChI}_{\max }$ & $Z_{D C M}$ & $Z_{\mathrm{CC}}$ \\
\hline Chlor $_{0}$ & 1.00 & & & & \\
\hline$C l_{\text {mean }}$ & $0.33 \cdots$ & 1.00 & & & \\
\hline $\mathrm{Chl}_{\max }$ & 0.01 & $0.80^{\circ}$ & 1.00 & & \\
\hline$Z_{\mathrm{DCM}}$ & $-0.48^{\prime} \cdot$ & 0.04 & 0.11 & 1.00 & \\
\hline$Z_{C C}$ & $-0.63^{*}$ & 0.03 & 0.13 & $0.80^{\circ}$ & 1.00 \\
\hline Temp $p_{0}$ & $-0.56^{\cdots}$ & -0.19 & 0.12 & $0.48^{\cdots}$ & $0.57^{\cdots}$ \\
\hline$D_{\text {sigt }}$ & $-0.46^{\cdots}$ & -0.20 & 0.12 & 0.22 & 0.26 \\
\hline$Z_{\mathrm{NO} 3}$ & $-0.46^{\cdots}$ & -0.17 & -0.11 & $0.75^{\cdots}$ & $0.78 \cdots$ \\
\hline$Z_{\mathrm{NO} 2}$ & $-0.28^{\circ}$ & 0.10 & 0.14 & $0.43^{\cdots}$ & $0.61^{\cdots}$ \\
\hline VSI & $-0.30^{\circ}$ & 0.16 & $0.59 \cdots$ & 0.00 & 0.04 \\
\hline Parameter & Tempo & $D_{\text {sigt }}$ & $Z_{\mathrm{NO} 3}$ & $Z_{\mathrm{NO} 2}$ & VSI \\
\hline Temp $p_{0}$ & 1.00 & & & & \\
\hline $\mathrm{D}_{\text {slgt }}$ & $0.88^{\cdots}$ & 1.00 & & & \\
\hline$Z_{\mathrm{NO} 3}$ & $0.54^{\circ}$ & 0.18 & 1.00 & & \\
\hline$Z_{\mathrm{NO} 2}$ & $0.45^{\circ}$ & $0.27^{\cdots}$ & $0.49^{\cdots}$ & 1.00 & \\
\hline VSI & $0.42^{\circ}$ & 0.57 & -0.08 & 0.08 & 1.00 \\
\hline
\end{tabular}




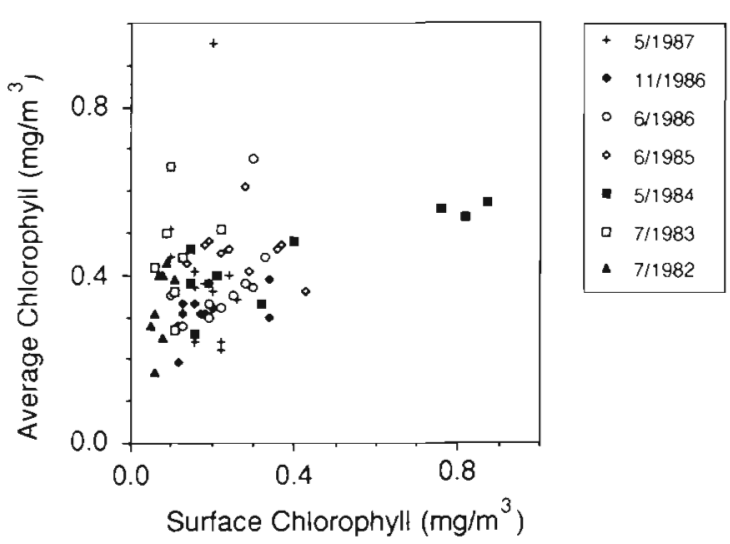

Fig. 7. Surface versus average chlorophyll a concentration in a layer of 0 to $110 \mathrm{~m}$ depth. The symbols indicate the different cruises

\section{Phytoplankton composition}

In the spring and summer cruises, the DCM was associated with an increase in the chlorophyll content per cell and to a phytoplankton abundance maximum. In general, different phytoplankton assemblages were found in the upper layers, dominated by flagellates and small dinoflagellates, and in the DCM, where patches of high diatom abundance could be found (Estrada 1985a, 1991). The most abundant diatom genera were Chaetoceros, Nitzschia, Rhizosolenia and Thalassiosira. The highest concentrations of diatoms in the DCM (mainly Chaetoceros spp., Nitzschia spp. and Leptocylindrus danicus) were found in some stations (e.g. Stn 10) of PEP 87. However, in a number of samples of this cruise, many of the cells appeared to be in bad shape, suggesting that they represented the late phase of a bloom. The silicoflagellate Dictyocha fibula and the diatoms Hemidiscus cuneiformis and Coscinodiscus radiatus were typically distributed, with low abundances, in the deeper part of the euphotic zone. During November 1986, deep phytoplankton maxima were less marked than in the cruises carried out earlier in the season, and the DCM did not always correspond to increased phytoplankton abundance (data not shown; this could have been due to a major contribution of higher chlorophyll a content per cell or to the presence of small organisms, easily disrupted and not included in the counts. Coccolithophorids, especially Emiliania huxleyi, together with small flagellates and dinoflagellates were the most abundant phytoplankton groups

\section{Primary production}

The available mid-day values of primary production for the biological stations of the central zone (Fig. 8)

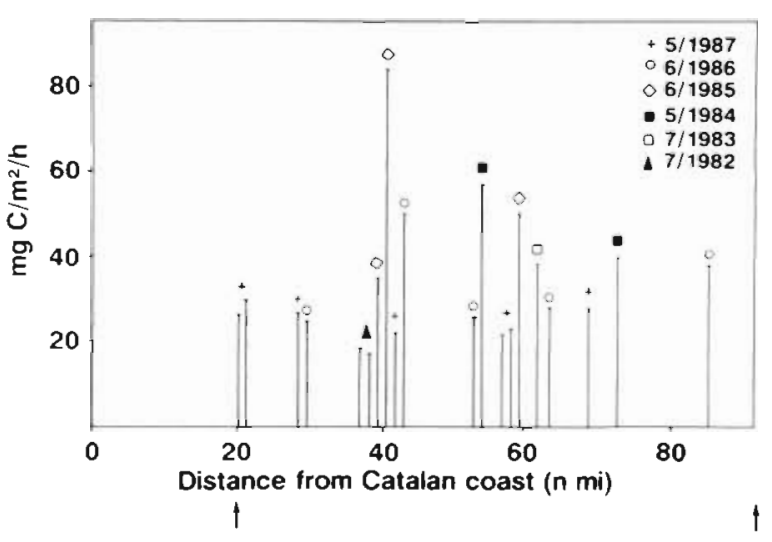

Fig. 8. Integrated primary production values $\left(\mathrm{mg} \mathrm{C} \mathrm{m}^{-2} \mathrm{~h}^{-1}\right)$ for the stations at the central zone of the transect. $\mathrm{n}$ mi: nautical miles. Arrows indicate the position of the $1000 \mathrm{~m}$ isobath

ranged from $17.4 \mathrm{mg} \mathrm{C} \mathrm{m}^{-2} \mathrm{~h}^{-1}$ in PEP 82 (Stn 23) to $83.6 \mathrm{mg} \mathrm{C} \mathrm{m}^{-2} \mathrm{~h}^{-1}$ in PEP 85 (Stn 24), with a median of about 30 . The integrated chlorophyll a values, down to the $1 \%$ light level, ranged from 16.1 to 60.3 , with a median of about 26 . The highest integrated primary production value was recorded during PEP 85, near the Catalan front.

There was often a primary production peak at depths coinciding with or slightly above the DCM, but in many cases the highest primary production values occurred in the upper euphotic zone (Estrada 1985a, b, and data not shown). The relation $(P / B)$ between hourly primary production Prod $_{\mathrm{nt}}, \mathrm{mg} \mathrm{C}(\mathrm{mg} \mathrm{chl} \mathrm{a})^{-1}$ $\mathrm{h}^{-1}$ ] and integrated chlorophyll a (Chlor ${ }_{\text {int }}, \mathrm{mg} \mathrm{m}^{-2}$ ) for the different cruises is shown in Fig. 9. Two of the points (corresponding to Stns 24 of PEP 85 and 10 of PEP 87, marked 24 and 10, respectively, in Fig. 9) were clear 'outliers' in the statistical sense; however, from a biological point of view, they were perhaps the most interesting in the data set. In the first case, the DCM was relatively shallow $(40 \mathrm{~m})$ and the surface layers

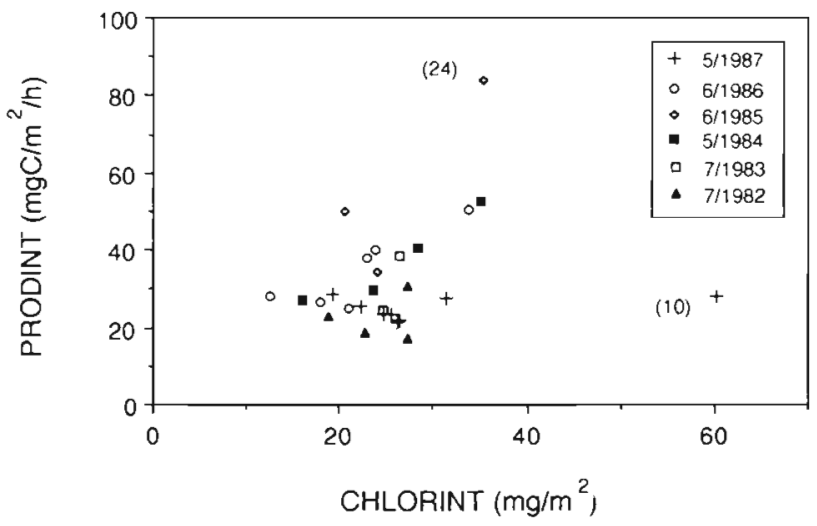

Fig. 9. Integrated chlorophyll a down the $1 \%$ light level (CHLORINT) versus integrated primary production (PRODINT). The symbols indicate the different cruises 
Table 4. Mean \pm standard error of $P / B$ (the ratio between integrated primary production, Prod int and integrated chlorophyll, Chlor Int $), P_{\max }^{B}$ (maximum productivity index in the water column), $P^{B}{ }_{\mathrm{DCM}}$ (productivity index at the DCM) and the ratio Prod ${ }_{\mathrm{c} a \mathrm{y}} /$ Chlor 0 (see text) for the biological stations of the different cruises

\begin{tabular}{lcccc|}
\hline Cruise & $P / B$ & $P_{\text {max }}^{B}$ & $P_{\text {DCM }}^{B}$ & Prod $_{\text {day }} /$ Chlor $_{0}$ \\
\hline PEP 84 & $1.46 \pm 0.04$ & $2.52 \pm 0.014$ & $0.66 \pm 0.29$ & $1679 \pm 260$ \\
PEP 87 & $0.94 \pm 0.10$ & $1.90 \pm 0.18$ & $0.58 \pm 0.20$ & $1154 \pm 67$ \\
PEP 85 & $2.07 \pm 0.33$ & $5.11 \pm 0.96$ & $1.08 \pm 0.44$ & $2029 \pm 260$ \\
PEP 86 & $1.61 \pm 0.08$ & $3.98 \pm 0.55$ & $0.66 \pm 0.10$ & $2248 \pm 289$ \\
PEP 82 +83 & $0.97 \pm 0.25$ & $3.32 \pm 0.39$ & $0.37 \pm 0.12$ & $2244 \pm 145$ \\
\hline
\end{tabular}

were occupied by a tongue of low salinity water, probably of coastal origin, containing a flagellate-dominated community which showed the highest productivity index recorded in this data set $16.6 \mathrm{mg} C(\mathrm{mg} \mathrm{chl}$ a) ${ }^{-1} \mathrm{~h}^{-1}$ for the surface samplel. At Stn 10 of PEP 87 , the chlorophyll concentrations between 70 and $90 \mathrm{~m}$ depth ranged from $1.76 \mathrm{mg} \mathrm{m}^{-3}$ to $3.92 \mathrm{mg} \mathrm{m}^{-3}$, the highest value found at the DCM. As discussed above, this biomass accumulation was due to a decaying diatom bloom, perhaps sedimented from upper depths. The data trom this station were excluded from the correlation and regression analyses.

For each cruise, mean values of $P / B$, the maximum productivity index at a discrete depth in the water column $\left[P_{\text {max }}^{B}, \operatorname{mg~} C(\operatorname{mg~chl~} a)^{-1} h^{-1}\right]$, the productivity index at the DCM depth $\left[P^{B}{ }_{D C M}, \operatorname{mg~C}\left(\mathrm{mg} \mathrm{chl} \mathrm{a}^{-1} \mathrm{~h}^{-1}\right]\right.$ and the ratio $\left(\operatorname{Prod}_{d a y} / \mathrm{Chlor}_{0}\right.$ ) between daily integrated production ( $\mathrm{mg} \mathrm{C} \mathrm{m}^{-2} \mathrm{~d}^{-1}$ ) and near-surface chlorophyll concentration ( $\mathrm{mg} \mathrm{m}^{-3}$ ) (Eppley et al. 1985) are given in Table 4 (due to the low number of samples, data for the July cruises, PEP 82 and PEP 83 were pooled). A Kruskal-Wallis 1-way analysis of variance indicated significant differences at the $1 \%$ level for $P^{B}{ }_{D C M}$ and at the $5 \%$ level for $P / B$. The highest $P / B$ values were found in late spring (PEP 85 and PEP 86), and the lowest in mid spring (Pep 84 and PEP 87) and summer (PEP 82+PEP 83). $P_{\text {max }}^{B}$ increased from mid to late spring and decreased again, but not as markedly as $P / B$, in summer. The ratio Prod $_{\text {day }} /$ Chlor $_{0}$ increased from spring to summer, but its variability was not significant at the $\mathrm{p}<0.05$ level.

The correlation coefficients of the primary production estimates $\left(\operatorname{Prod}_{\text {int }}\right)$ and the $P / B$ ratio with some of the physico-chemical and biological variables measured at the same stations are given in Table 5 . Significant positive correlations were found between

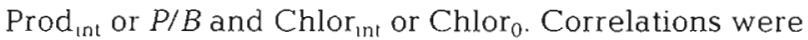
negative between $P_{\text {rod }}$ or $P / B$ and $Z_{D C M}$ or the depth of the $1 \%$ light level, which was taken as the depth of the euphotic zone $\left(Z_{e u}\right)$. The between-cruise variability

Table 5. Correlation coefficients of integrated primary production ( $\operatorname{Prod}_{1 \mathrm{nt}}, \mathrm{mg} \mathrm{C} \mathrm{m}^{-2} \mathrm{~h}^{-1}$ ) and the ratio between Prodint and integrated chlorophyll down to the $1 \%$ light level $\left[P / B, \mathrm{mg} \mathrm{C}(\mathrm{mg} \mathrm{chl} \mathrm{a})^{-1}\right]$ with several parameters measured at the biological casts. The number of observations was 18 to 20 . Significance: $0.01<p<0.05 ; \cdots p<0.01$. The key for abbreviations is given in Table 2

\begin{tabular}{|c|c|c|c|c|c|c|c|c|c|c|}
\hline & Chlor $_{\text {in: }}$ & Chlor $_{0}$ & $C h l_{\operatorname{muax}}$ & $Z_{D C M}$ & $Z_{\mathrm{CC}}$ & Temp $p_{0}$ & $\mathrm{D}_{\text {sig: }}$ & $Z_{N O 3}$ & VSI & $\mathcal{Z}_{\mathrm{eu}}$ \\
\hline Prod $_{1 \Omega t}$ & $0.53 \cdots$ & $0.61 *$ & -0.04 & $-0.47 \cdots$ & -0.29 & -0.22 & $0.60 \cdots$ & -0.18 & -0.34 & $-0.46^{\circ}$ \\
\hline$P / B$ & - & -0.15 & -0.14 & -0.19 & -0.07 & -0.02 & $0.57^{\cdots}$ & 0.02 & -0.38 & $-0.60 \cdots$ \\
\hline
\end{tabular}

Table 6. Multiple linear regression coefficients and variance explained. $n=$ no. of observations. The key for abbreviations is given in Table 2

\begin{tabular}{|c|c|c|c|c|c|c|c|c|c|}
\hline \multirow[t]{2}{*}{ Model } & \multirow[t]{2}{*}{$\mathrm{n}$} & \multirow{2}{*}{$\begin{array}{c}\text { Response } \\
\text { variable }\end{array}$} & \multicolumn{4}{|c|}{ Independent variables } & \multirow[t]{2}{*}{ Intercept } & \multirow[t]{2}{*}{$r^{2}$} & \multirow[t]{2}{*}{$\mathrm{p}$} \\
\hline & & & Chlor $_{D}$ & Chlor $_{\text {int }}$ & $\mathrm{D}_{\text {sig: }}$ & $Z_{\mathrm{eu}}$ & & & \\
\hline 1 & 20 & Prod $_{1 \mathrm{nt}}$ & 100.0 & - & - & - & 14.3 & 0.37 & $<0.01$ \\
\hline 2 & 20 & $\operatorname{Prod}_{1 n t}$ & - & 1.44 & - & - & -2.63 & 0.28 & $<0.05$ \\
\hline 3 & 18 & Prod $_{1 n t}$ & - & 1.34 & 6.81 & - & -18.1 & 0.62 & $<0.01$ \\
\hline 4 & 18 & $\operatorname{Prod}_{1 n t}$ & - & 1.39 & 5.87 & -0.64 & 24.9 & 0.74 & $<0.01$ \\
\hline
\end{tabular}


discussed in the previous paragraph was reflected in a relatively low correlation between Prod $_{\text {int }}$ and Chlor int when the pooled data set was considered. The ratio $P / B$ was negatively correlated with $Z_{\text {eu }}$. Exclusion of the data corresponding to Stn 24 of PEP 85 made nonsignificant (but still positive) the correlation between Prod $_{1 n t}$ and $P / B$ with $D_{\text {sigt }}$.

Several descriptive regression models were formulated with Prodint as the response variable and one or more of the variables of Table 5 as independent variables. Some of them are given in Table 6. Models 1 and 2 , with Chlor $_{0}$ or Chlor Int $_{\text {as }}$ independent variables explained respectively 37 and $28 \%$ of the variance. Addition of $T e m p_{0}$ as independent variable did not improve the regression fit of Models 1 or 2. Model 3, with Chlor $_{\text {int }}$ and $\mathrm{D}_{\text {sigt }}$, and Model 4 , with these and $Z_{\text {eu }}$ as dependent variables explained, respectively, 62 and $74 \%$ of the variance. Exclusion of the high Prod ${ }_{i n t}$ value of Stn 24 of PEP 85 resulted in a lower percentage of the data variance explained by the regression equations (36 and $61 \%$ for Models 3 and 4, respectively).

\section{DISCUSSION}

In spite of interannual variability, which was particularly apparent in the two May cruises (Figs. 4 to 6), the DCM-related parameters showed trends which fit well into the generally accepted picture of the seasonal cycle in the Northwestern Mediterranean (Margalef \& Castellvi 1967). The spring to fall deepening of $Z_{\mathrm{NO}_{3}}$ with respect to $Z_{\mathrm{DCM}}$ and $Z_{\mathrm{CC}}$ suggests a seasonal decrease of nitrate supply to the DCM community. Presumably, this observation can also be applied to the supply of phosphate, another major nutrient likely to be limiting in Mediterranean waters. The phosphate data were too fragmentary to be included here, but the available profiles showed that generally the depth of the phosphate nutricline coincided or was close to that of the nitracline. Assuming that the nitrate distribution is representative of nitrogen supply conditions at the DCM, a progressive reduction of new production from spring to fall could be expected. This may not be reflected in the primary production estimates derived from ${ }^{14} \mathrm{C}$ experiments, which are likely to include a strong component of regenerated production.

Significant relationships for DCM-related parameters, comparable to those given in Table 3 , have been found in other areas, including the Southwestern Mediterranean (Herbland \& Voituriez 1979, Cullen \& Eppley 1981, Cox et al. 1982, Lohrenz et al. 1988). In these studies, $Z_{\mathrm{DCM}}$ was strongly correlated with $Z_{\mathrm{NO}_{3}}$, suggesting the importance of the upward nutrient flux in influencing the vertical chlorophyll distribution. In contrast with the results of Herbland \& Voituriez (1979) for the tropical Atlantic Ocean, our data did not show a significant correlation between $\mathrm{Chl}_{\max }$ and $Z_{\mathrm{DCM}}$. This finding may be related to the relative importance of growth versus loss factors on the build-up of chlorophyll concentration at the DCM. In situations of relatively intense growth at the DCM (such as would occur in the equatorial upwelling, with a relatively shallow DCM), Chl max would show a negative correlation with $Z_{\mathrm{DCM}}$, as found by Herbland \& Voituriez (1979). Under conditions of relatively slow growth, reduced losses (lower turbulent dispersion rates) would be relatively more important in maintaining a high $\mathrm{Chl}_{\max }$ and this variable would show positive or non-significant correlation with $Z_{D C M}$, because $Z_{D C M}$ tends to become deeper when stratification increases. This would be the case of our observations and those of Cox et al. (1982) for Sargasso waters. The negative (but non-significant) correlation betwen $Z_{D C M}$ and $\mathrm{Chl}_{\max }$ found by Lohrenz et al. (1988) for the Southwestern Mediterranean would indicate an intermediate situation. Of course, other factors, such as grazing pressure could modify this oversimplified scenario.

Interaction of light availability and nutrient supply within a layer of reduced turbulence appears to play a leading role in the formation and location of the DCM in the Western Mediterranean (Estrada 1985a, Lohrenz et al. 1988). Chlorophyll patchiness within the DCM could be explained by variability in physical forcing. Shoaling of the DCM due to wind events, instabilities or upwelling phenomena at the front would result in intermittent increases of nutrient flux into the euphotic zone and enhancement of in situ growth which would be difficult to detect with conventional sampling strategies (Estrada 1985a, Dandonneau \& Lemasson 1987. Eppley et al. 1988, Lohrenz et al. 1988, Strass 1992).

The primary production rates estimated in this study fall within the ranges reported in Sournia (1973) for the Northwestern Mediterranean. Our range (after extrapolation to daily values) of 0.16 to $0.76 \mathrm{~g} \mathrm{C} \mathrm{m}^{-2} \mathrm{~d}^{-1}$ is similar to that $\left(0.33\right.$ to $\left.0.60 \mathrm{~g} \mathrm{C} \mathrm{m}^{-2} \mathrm{~d}^{-1}\right)$ given by Lohrenz et al. (1988) for Mediterranean Waters north of the Algerian Current front (Southwestern Mediterranean). However, given the differences in spatial and temporal coverage, it is difficult to establish detailed comparisons with previously reported data sets.

The between-cruise differences of the photosynthetic parameters listed in Table 4 are likely to reflect a combination of seasonal trends and smaller scale (both temporal and spatial) variability in the taxonomic and physiological characteristics of the autotrophic plankton community. Lower mean values of $P^{B}$ max in the mid spring (May) cruises could be related to shade adaptation of the cells, due to a higher degree of mixing of the water column early in the season (Lewis et al. 1984, Gallegos \& Platt 1985). Increased stability of the upper 
euphotic zone of the June and July cruises could have contributed to higher photosynthetic capacities of the resident flagellate-dominated populations (Demers \& Legendre 1982, Perissinotto et al. 1990). The increase in $P^{B}{ }_{\text {max }}$ from mid to late spring would tend to raise the $\operatorname{Prod}_{d a y} / \mathrm{Chlor}_{0}$ ratios, but effects on total production and $P / B$ could be offset later on (summer) by factors such as a deeper position of the DCM and the nutricline, which would tend to decrease the relative proportion of total incident light available for the autotrophs (Lorenzen 1971). Our findings agree with the observations of Eppley et al. (1985) and Eppley et al. (1987) in the Southern California Bight and the Eastern Tropical Pacific Ocean. These authors recorded that highest values of $\mathrm{Prod}_{\mathrm{day}} / \mathrm{Chlor}_{0}$ were found in oligotrophic or stratified (summer) waters and lowest values in nutrient-rich or mixed (winter) waters.

Among the possible explanations for the finding of weak or non significant relationshins between chlorophyll, primary production and vertical nutrient distributions are the effects of patchiness and the input of nutrients by advection, isopycnal mixing, or other processes not directly dependent on diffusion across the nutricline (Ohman et al. 1982, Hayward 1987). Both explanations may apply to our study area, which is likely to be affected by instabilities of the neighbouring frontal zones. In a strict sense, our results do not fit all the characteristics given by Herbland \& Voituriez (1979) for the TTS, although the basic mechanisms of DCM formation are likely to be the same. It should be noted also that the data of Herbland \& Voituriez (1979) covered a range of situations going from nitracline depths of about 20 to $90 \mathrm{~m}$, wider than that found in our work; this may have been another cause for the lower correlations obtained with our data.

As can be seen in Table 6, some combinations of independent variables (e.g. Models 3 and 4) provided satisfactory fit to the integrated production data, with or without the high production point of Stn 24 of PEP 85 . It needs to be investigated whether future data will support the usefulness of these or similar regression models. It is interesting to note that, when taken alone, Chlor $_{0}$ was a better predictor of production than Chlor $_{\text {inti }}$ however, when other variables were considered, use of Chlor int instead of Chlor 0 resulted in greater variance explained. The positive effect of $D_{\text {sigt }}$ reflects the finding, discussed above, of higher assimilation numbers of upper euphotic zone communities with increased stability. The euphotic zone depth $\left(Z_{\mathrm{eu}}\right)$ presented a negative relationship with production, as found in previous studies (Lafontaine \& Peters 1986). A limitation of our data set is the lack of adequate measurements of incident irradiance during the incubations. However, most incubation experiments were carried out on sunny days and radiation conditions for the studied zone vary little between May and July (Coronas et al. 1982). Thus, it could be expected that incident irradiance per se would be of little predictive value, as discussed by Harrison \& Platt (1980), Lafontaine \& Peters (1986) and Banse \& Yong (1990).

The study of regional differences and relationships among parameters describing photosynthetic characteristics and vertical distribution of autotrophic biomass is of interest for large scale estimation of primary production. Available data suggest that such parameters show some seasonal and geographical trends and could be useful for the broad characterization of marine regions in the remote sensing context (Eppley et al. 1985, Platt \& Sathyendranath 1988). Often, however, as found in the present work and in other studies of regions with deep chlorophyll maxima (Hayward \& Venrick 1982, Ohman et al. 1982. Hayward 1987, Banse \& Yong 1990), only relatively low variance can be explained by the regression of primary production on chlorophyll, or on variables which might be readily determined by remote sensing. It is likely that statistical 'outliers' will continue to be a problem in such regressions, emphasizing the need to consider the composition and physiological variability of the autotrophic populations, in order to make accurate predictions of primary production. This implies a limitation for current remote sensing applications, as noted by Banse \& Yong (1990); however, in a general context, although disturbing when trying to summarize results, the presence of 'outliers' may provide interesting information that should not be overlooked.

Acknowlegdements. We thank the crew of the RV 'García del Cid' and the other participants in the cruises for their help during sampling. M. Alcaraz and R. Margalef made valuable comments on the manucript. A. Cruz, J. Biosca, P. Sacristán and M. Vélez provided technical assistance. This work was supported by the Consejo Superior de Investigaciones Cientificas, by grant nos. 2311308 and PR84-0067 of the CAICYT and by grant no. CCA8411054 of the Comité Conjunto Hispano-norteamericano para la Cooperación Científica y Tecnológica.

\section{LITERATURE CITED}

Anderson, G. C. (1969). Subsurface chlorophyll maximum in the Northeast Pacific Ocean. Limnol. Oceanogr. 14: $386-391$

Balch, W., Evans, J., Brown, J., Feldman, G., McClain, C., Esaias, W. (1992). The remote sensing of ocean primary productivity: use of a new data compilation to test satellite algorithms. J. geophys. Res. 97 C: 2279-2293

Banse, K., Yong, M. (1990). Sources of variability in satellitederived estimates of phytoplankton production in the Eastern Tropical Pacific. J. geophys. Res. 95C: $7201-7215$

Berman, T., Townsend, D. W., El-Sayed, S. Z., Trees, C. C., Azov, Y (1984). Optical transparency, chlorophyll and pri- 
mary productivity in the Eastern Mediterranean near the Israeli coast. Oceanol. Acta 7: 367-372

Coronas, A., Llorens, M., Villarrubia, M. (1982). Energia solar a Catalunya: Radiació solar i insolació. Universitat de Barcelona, Publicacions i Edicions, Barcelona

Cox, J. L., Wiebe, P. H., Ortner, P., Boyd, S. (1982). Seasonal development of subsurface chlorophyll maxima in Slope Water and Northern Sargasso Sea of the Northwestern Atlantic Ocean. Biol. Oceanogr 1.271-285

Cullen, J. J. (1982). The deep chlorophyll maximum: comparing vertical profiles of chlorophyll a. Can. J. Fish. Aquat. Sci. 39: 791-803

Cullen, J. J., Eppley, R. W. (1981). Chlorophyll maximum layers of the Southern California Bight and possible mechanisms of their formation and maintenance. Oceanol. Acta 4: $23-32$

Dandonneau, Y., Lemasson, L. (1987). Water-column chlorophyll in an oligotrophic environment: corection for the sampling depths and variations of the vertical structure of density, and observation of the growth period. J. Plankton Res, 9: 215-234

Demers, S., Legendre, L. (1982). Water column stability and photosynthetic capacity of estuarine phytoplankton: longterm relationships. Mar. Ecol. Prog. Ser. 7: 337-340

Eppley, R. W., Stewart, E., Abbott, M. R., Heyman, U. (1985). Estimating ocean primary production from satellite chlorophyll. Introduction to regional differences and statistics for the Southern California Bight. J. Plankton Res. 7: $57-70$

Eppley, R. W., Stewart, E., Abbott, M. R., Owen, R. W. (1987). Estimating ocean production from satellite-derived chlorophyll: insights from the Eastropac data set. Oceanol. Acta Special Issue 6: 109-113

Eppley, R. W., Swift, E., Redalje, D. G., Landry, M. R., Haas, L. W. (1988). Subsurface chlorophyll maximum in August-September 1985 in the CLIMAX area of the North Pacific. Mar. Ecol. Prog. Ser. 42: 289-301

Estrada, M. (1985a). Deep phytoplankton and chlorophyll maxima in the Western Mediterranean. In: MoraitouApostolopoulou, M., Kiortsis, V. (eds.) Mediterranean marine ecosystems. Plenum Press, New York, p. 247-277

Estrada, M. (1985b). Primary production at the deep chlorophyll maximum in the Western Mediterranean. In: Gibbs, P. E. (ed.) Proc. 19th Eur. Mar. Biol. Symp. Cambridge University Press, Cambridge, p. 109-121

Estrada, M. (1991). Phytoplankton assemblages across a NW Mediterranean front: changes from winter mixing to spring stratification. In: Ros, J. D., Prat, N. (eds.) Homage to Ramon Margalef; or. Why there is such pleasure in studying nature. Oecologia Aquatica 10:157-185

Estrada, M., Margalef, R. (1988). Supply of nutrients to the Mediterramean photic zone across a persistent front. Oceanol. Acta Special Issue 9: 133-142

Estrada, M., Salat, J. (1989). Phytoplankton assemblages of deep and surface water layers in a Mediterranean frontal zone. Scientia Marina 53: 203-214

Fairbanks, R. G., Wiebe, P. H. (1980). Foraminiferan and chlorophyll maximum: vertical distribution, seasonal succession, and paleoceanographic significance. Science 209: $1524-1529$

Gallegos, C. L., Platt, T (1985). Vertical advection of phytoplankton and productivity estimates: a dimensional analysis. Mar. Ecol. Prog. Ser. 26: 125-134

Harrison, W. G., Platt, T. (1980). Variations in assimilation number of coastal marine phytoplankton: effects of environmental co-variates. J. Plankton Res. 2: 249-260

Hayward, T. L. (1987). The nutrient distribution and primary production in the central North Pacific. Deep Sea Res. 34: 1593-1627

Hayward, T L., Venrick, E. L. (1982). Relation between surface chlorophyll, integrated chlorophyll and integrated primarv production. Mar. Biol. 69: 247-252

Herbland, A., Le Borgne, R., Le Bouteiller, A., Voituriez, B. (1983). Structure hydrologique et production primaire dans l'Atlantique tropical oriental. Océanogr Trop. 17 : $15-25$

Herbland, A., Voituriez, B. (1979). Hydrological structure analysis for estimating the primary production in the tropical Atlantic Ocean. J. mar. Res. 37: 87-101

Herman, A. W. (1989). Vertical relationships between chlorophyll, production and copepods in the eastern tropical Pacific. J. Plankton Res. 11: 243-261

Kiefer, D. A., Olson, R. J., Holm-Hansen, O. (1976). Another look at the nitrite and chlorophyll maxima in the central North Pacific. Deep Sea Res. 23: 1199-1208

Lafontaine, Y., Peters, R. H. (1986). Empirical relationship for marine primary production: the effect of environmental variables. Oceanol. Acta 9:65-72

Laws, E. A., DiTullio, G. R., Redalje, D. G. (1987). High phytoplankton growth and production rates in the North Pacific subtropical gyre. Limnol. Oceanogr. 34: 905-918

Lewis, M. R., Cullen, J. J., Platt, T (1984). Relationships between vertical mixing and photoadaptation of phytoplankton: similarity criteria. Mar. Ecol. Prog. Ser 15: $141-149$

Lohrenz, S. E., Wiesenburg, D. A., DePalma, I. P., Johnson, K. S., Gustafson, D. E. (1988). Interrelationships among primary production, chlorophyll, and environmental conditions in frontal regions of the western Mediterranean Sea. Deep Sea Res. 35: 793-810

Lohrenz, S. E., Wiesenburg, D. A., Rein, C. R., Arnone, R. A., Taylor, C. D., Knauer, G. A., Knap, A. H. (1992). A comparison of in situ and simulated in situ methods for estimating oceanic primary production. J. Plankton Res. 14: 201-221

Lorenzen, C. J. (1971). Extinction of light in the ocean by phytoplankton. J. Cons. int. Explor. Mer 34: 262-267

Margalef, R. (1985). Environmental control of the mesoscale distribution of primary producers and its bearing to primary production in the Western Mediterranean. In: Moraitou-Apostolopoulou, M., Kiortsis, V. (eds.) Mediterranean marine ecosystems. Plenum Press, New York, p. 213-229

Margalef, R., Castellvi, J. (1967). Fitoplancton y producción primaria de la costa catalana, de julio de 1966 a julio de 1967. Investigación pesq. 31:491-502

Margalef, R., Estrada, M. (1987). Synoptic distribution of summer phytoplankton (Algae and Protozoa) across the principal front in the Western Mediterranean. Investigación pesq. 51: $121-140$

Masó, M., Grup PEPS (1988). Datos oceanográficos básicos de las campañas FRONTS-3-85, FRONTS-6-85, PEP 86, FRONTS-11-86 y PEP 87 en el mar Catalán. Datos Informativos $24: 1-83$

Minas, H. J., Coste, B. (1964) Étude de la structure hydrologique et de quelques aspects de la productivité de la zone euphotique en fin d'été au niveau d'une station fixe (bouée-laboratoire de COMEXO) et rade de Villefranche s/mer. Recueil des Travaux de la Station marine d'Endoume, Faculté des Sciences de Marseille 34: $133-255$

Napp, J. M. (1987). Primary productivity maxima in the Southern California Bight: distribution, predicted depth and nutritional content. Oceanol. Acta 10:329-337

Ohman, M., Anderson, G. C.. Ozturgut, E. (1982). A multivar- 
iate analysis of planktonic interactions in the eastern tropical North Pacific. Deep Sea Res. 29: 1451-1469

PEPS, Grup (1986). Datos oceanográfıcos básicos de las campañas PEP-82, PEP-83 y PEP-84 en el mar Catalán. Datos Informativos 19: 1-52

Perissinotto, R., Duncombe Rae, C. M., Boden, B. P., Allanson, B. R. (1990). Vertical stability as a controlling factor of the marine phytoplankton production at the Prince Edward Archipelago (Southern Ocean). Mar. Ecol. Prog. Ser. 60: 205-209

Phinney, D. A., Yentsch, C. S. (1983). A novel phytoplankton chlorophyll technique: toward automated analysis. J Plankton Res. 7: 633-642

Platt, T., Sathyendranath, S. (1988). Oceanic primary production: estimation by remote sensing at local and regional scales. Science 241: 1613-1620

Sheldon, R. W. (1972). Size separation of marine seston by

This article was submitted to the editor membrane and glass-fiber filters. Limnol. Oceanogr, 17 : $494-498$

Sournia, A. (1973). La production primaire planctonique en Méditerranée. Essai de mise à jour. Bull. Ét. Comm. Médit. Special Issue 5: $1-128$

Strass, V. H. (1992). Chlorophyll patchiness caused by mesoscale upwelling at fronts. Deep Sea Res. 39: 75-96

Venrick, E. L., Cummings, S. L., Kemper, C. A. (1987). Picoplankton and the resulting bias in chlorophyll retained by traditional glass-fiber filters. Deep Sea Res. 34 : $1951-1956$

Venrick, E. L., McGowan, J. A., Mantyla, A. W. (1973). Deep maxima of photosynthetic chlorophyll in the Pacific Ocean. Fish. Bull. U.S. 71: 41-52

Yentsch, C. S., Menzel, D. W. (1963). A method for the determination of phytoplankton chlorophyll and phaeophytin by fluorescence. Deep Sea Res. 10: 221-231

Manuscript first received: June 11, 1992

Revised version accepted: December 14, 1992 